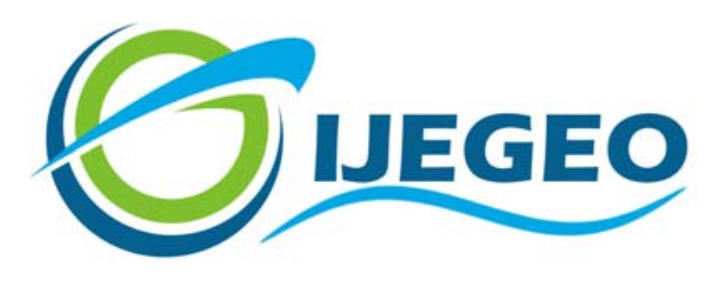

International Journal of Environment and Geoinformatics (IJEGEO) is an international, multidisciplinary, peer reviewed, open access journal.

\title{
The Effects of Safety Culture on Occupational Accidents: An explanatory study in Container Terminals of Turkey
}

\section{Murat Selçuk SOLMAZ, Pelin ERDEM, Gökçe BARIŞ}

\author{
Chief in Editor \\ Prof. Dr. Cem Gazioğlu \\ Co-Editors \\ Prof. Dr. Dursun Zafer Şeker, Prof. Dr. Şinasi Kaya, \\ Prof. Dr. Ayşegül Tanık and Assist. Prof. Dr. Volkan Demir
}

Editorial Committee (December 2020)

\begin{abstract}
Assos. Prof. Dr. Abdullah Aksu (TR), Assit. Prof. Dr. Uğur Algancı (TR), Prof. Dr. Bedri Alpar (TR), Prof. Dr. Levent Bat (TR), Prof. Dr. Paul Bates (UK), İrşad Bayırhan (TR), Prof. Dr. Bülent Bayram (TR), Prof. Dr. Luis M. Botana (ES), Prof. Dr. Nuray Çağlar (TR), Prof. Dr. Sukanta Dash (IN), Dr. Soofia T. Elias (UK), Prof. Dr. A. Evren Erginal (TR), Assoc. Prof. Dr. Cüneyt Erenoğlu (TR), Dr. Dieter Fritsch (DE), Prof. Dr. Çiğdem Göksel (TR), Prof.Dr. Lena Halounova (CZ), Prof. Dr. Manik Kalubarme (IN), Dr. Hakan Kaya (TR), Assist. Prof. Dr. Serkan Kükrer (TR), Assoc. Prof. Dr. Maged Marghany (MY), Prof. Dr. Michael Meadows (ZA), Prof. Dr. Nebiye Musaoğlu (TR), Prof. Dr. Masafumi Nakagawa (JP), Prof. Dr. Hasan Özdemir (TR), Prof. Dr. Chryssy Potsiou (GR), Prof. Dr. Erol Sarı (TR), Prof. Dr. Maria Paradiso (IT), Prof. Dr. Petros Patias (GR), Prof. Dr. Elif Sertel (TR), Prof. Dr. Nüket Sivri (TR), Prof. Dr. Füsun Balık Şanlı (TR), Prof. Dr. Uğur Şanlı (TR), Duygu Ülker (TR), Prof. Dr. Seyfettin Taş (TR), Assoc. Prof. Dr. Ömer Suat Taşkın (US), Assist. Prof. Dr. Tuba Ünsal (US), Dr. İnese Varna (LV), Dr. Petra Visser (NL), Prof. Dr. Selma Ünlü (TR), Prof. Dr. Murat Yakar (TR), Assit. Prof. Dr. Sibel Zeki (TR)
\end{abstract}

Abstracting and Indexing: TR DIZIN, DOAJ, Index Copernicus, OAJI, Scientific Indexing Services, International Scientific Indexing, Journal Factor, Google Scholar, Ulrich's Periodicals Directory, WorldCat, DRJI, ResearchBib, SOBIAD 


\title{
The Effects of Safety Culture on Occupational Accidents: An explanatory study in Container Terminals of Turkey
}

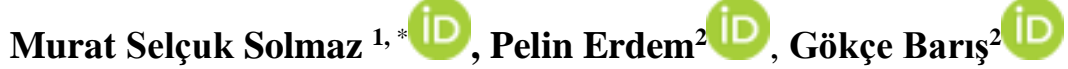 \\ ${ }^{1}$ Pîrî Reis University, Faculty of Engineering, Department of Industrial Engineering, İstanbul / TR \\ ${ }^{2}$ Pîrî Reis University, Maritime Faculty, Department of Maritime Transportation and Management Engineering, İstanbul / TR \\ * Corresponding author: Murat Selçuk Solmaz \\ *E-mail: mssolmaz@pirireis.edu.tr \\ Received 06 July 2019 \\ Accepted 06 Oct 2019
}

How to cite: Solmaz et. al. (2020). The Effects of Safety Culture on Occupational Accidents: An explanatory study in Container Terminals of Turkey. International Journal of Environment and Geoinformatics (IJEGEO), 7(3): 356-364. DOI: 10.30897/ijegeo.749735

\begin{abstract}
Detection of the underlying mechanisms leading to accidents resulting in fatalities and injuries is crucial to improve maritime safety. This paper examines the association between safety culture and occupational accidents in the container terminals. Within the scope of the study, six different container terminals that are situated in the Marmara Region were selected as application areas in Turkey. For the purpose of gathering information, a survey has been conducted with 134 respondents and interview has been carried out with the occupational safety specialists of ports, respectively. Collected data were analysed using SPSS 22 software to determine the safety culture level of terminals and their correlation with accidents. Data obtained from six container terminals were presented and results were discussed with respect to safety culture assessment and occupational accidents. The results highlight that the positive safety culture has a strong influence on port workers in terms of avoiding accidents. Additionally, each component related to safety culture was found in a significant correlation with the occurrences of accidents. Then again, port workers found to be rarely involved in accidents in case the safety culture level is high.
\end{abstract}

Keywords: Safety Culture, Occupational Accident, Container Terminal, Port Workers

\section{Introduction}

Shipping is one of the most dangerous industries in the world due to including high-level occupational risks. Therefore, the concept of safety culture as a means of reducing the potential for disasters, accidents, and incidents related to work becomes rather important increasingly (Cooper, 2000). Most of the researchers worked on safety issues emphasized that safety culture and safety climate are the key predictors of safety behaviours in an organization (Havold, 2007). Especially, organizational culture is an important construct that influences employees' awareness, attitudes, and behaviours related to safety (Simone, 2014). Cooper (2000) defines the safety culture as a sub-component of corporate culture, which alludes to the individual, job, and organizational features that affect and influence health and safety.

International Maritime Organization (IMO), as the global standard-setting authority for the safety, point out that safety and the promotion of an effective safety culture are the main issues in terms of preventing occupational accidents for shipping industry (IMO, 2003). The impact and the contribution of the safety culture to prevent occupational accidents and incidents were examined in the current study. Components of safety culture were identified for determining the cultural level of terminals and occupational hazards and accidents were examined and categorized in appointed container terminals in line with the objective.

\section{Safety Culture and Its Components}

The term 'safety culture' first appeared in the International Atomic Energy Agency's (IAEA) initial report on the Chernobyl nuclear accident (Cox and Flin, 1998). In the late 1980s 'safety culture' gained more importance for organizations in terms of both managerial and individual due to the occurrence of large-scale accidents. Safety culture has plenty of definitions in the literature. Bhattacharya (2015) defined the safety culture as a broad term representing all aspects of an organization's values and actions related to safety. In other words, safety culture embodies values, beliefs, norms and underlying assumptions safety-related issues. The Confederation of British Industry pointed out that safety culture is the ideas and beliefs that all members of the organisation share about risk, accidents and ill health (Cooper, 2000; Vega, 2002; Berg, 2013).

An organisation's safety culture is the production of individual and group values, attitudes, perceptions, competencies and behaviours determining the commitment to, and the way and proficiency of an organisation's health and safety management (Health and Safety Executive [HSE], 2005). Uttal's (1983) definition of safety culture points out shared values and beliefs that 
interact with an organization's structures and control systems to produce behavioural norms (Reason, 1998).

Effective safety culture should not only be a tool used for accident occurrences but also it should be a working style penetrating to entire employees' safety attitude in an organization. Krause indicates that safety culture is a guide to a correct way of thinking, feeling and behaviour in relation to safety (Martyka and Lebecki, 2014). Accordingly, the main purpose of safety culture is to be improving workplace safety and minimize occupational risks. In an organization, well-developed safety culture is an enabler for sustaining and improving safety and the emphasis placed on safety work and improvement processes for safety (Ek et. al., 2014). According to HSE researches organizations that have well-developed, functional and proactive health and safety management are likely to experience far less work-related accidents and incidents (Ek et. al., 2014). It is clearly seen that one of the main causes of accidents is lack of safety culture in an organization. To achieve a high-level safety culture, employees should be aware of the individual technical, organizational, and environmental risk factors that determine the work safety in order to perceive potential safety vulnerabilities. As a leading indicator of the safety performance of an organization, safety culture comprises of some key components. These six major and interrelated components of safety culture are given below in Figure 1.

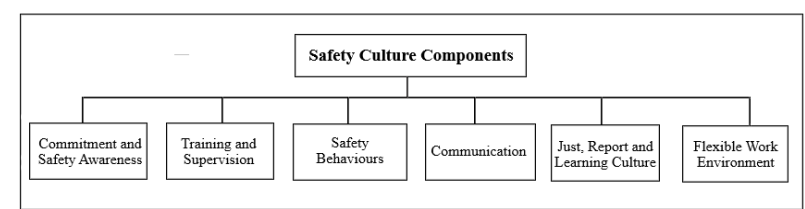

Figure 1. The key components of Safety Culture

In general, factors forming the major components to describe the structure of the safety culture are given in Figure 2. These factors were adapted from the safety culture components based on the previous researches (Zohar, 1980; O'Toole, 2002; Glendon and Stanton, 2000; Reason, 1998; Havold, 2000; Hudson, 1999; HSE, 2000; Cooper, 2000; Ek and Akselsson, 2005; Yüce and Gazioğlu, 2006; ICAO, 2006; Ek et. al., 2014; Terzi and Gazioğlu, 2014-2016; Yücel and Yurtören, 2019) which include both theoretical and measurement safety culture models.

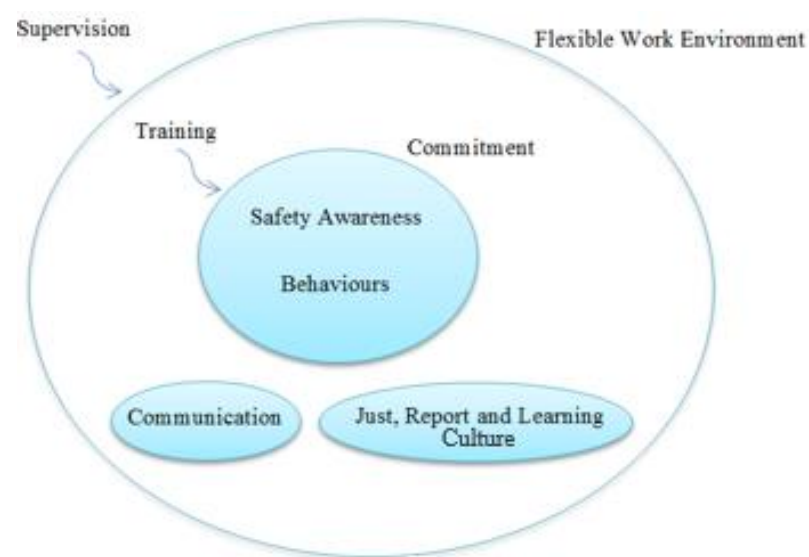

Figure 2. Factors interaction forming major components

\section{Commitment and Safety Awareness}

The safety culture of an organization, as a role model, has a considerable influence on employees' perceptions, awareness and behaviours related to safety issues. Promoting and maintaining the prevailing safety culture is thus an important part of the safety management process within the organizations (HSE, 2001). Strong safety performance carried out by the collective behaviours of employees (White, 2017). Individuals or groups can influence and drive safety culture both directly and indirectly through their actions and commitment (HSE, 2000). Employees' attitudes towards work safety and organizational commitment are two important elements in terms of performance and job satisfaction (Simone, 2014). Additionally, the organization's management and employees' beliefs in safety will drive employees emotionally to do safe acts (Afifi, 2015). Therefore, in case the employees are not internally motivated to generate the possible safest work environment, or if employees do not have a commitment to management related to safety issues, the organization's efforts for promoting and improving safety culture will be insufficient. However, the employees are supposed to accept and commit safety as the core element in their routine and non-routine tasks.

\section{Training and Supervision}

Most widely used method for promoting and improving safety in the workplace is to change employees' safety attitudes and then behaviours via safety training (Cooper, 2001). Training is a common practice for operational employees working in potentially dangerous and timecritical conditions (Marais et. al. 2004). A positive safety culture procures high qualified safety training presenting technical and tactical information to employees in an organization. Huang and his colleagues emphasised that organizations should have structural policies such as safety training and safety equipment for a strong belief about safety (Hahn and Murphy, 2008). To measure and to ensure the sufficiency of their safety policies and safety training, both internal and external audits should come into prominence.

\section{Safety Behaviours}

In any organisation, employees are the core element for safety culture. Especially, procedural violations and unsafe behaviours of employees are the reflections of insufficient safety management of an organization. Besides, safety behaviour refers to employee risk-taking behaviour and compliance with safety rules and procedures (Drupsteen and Boustras, 2015). In other words, the behavioural aspect is about "what people do" (Cooper, 2000). Each employee of an organisation should believe that safety is everyone's responsibility. Safety culture is formed implicitly when individual safety attitudes develop and safety behaviours are promoted ( $\mathrm{Lu}$ and Tsai, 2010). Therefore, organizational safety culture should influence individual safety values, attitudes and behaviours related to safety. When safety policy is emphasized in an organization, the value towards safety will be transmitted from management to the employees' behaviour (Lu and Tsai, 2010). 


\section{Communication}

The efficiency of health and safety communications within the organisation is the key safety message for an organization (Motter and Santos, 2017). Communicating problems without hesitation, exchanging ideas and information between employees are the important factors of organizations' safety culture (Bhattacharya, 2015). American Bureau of Shipping (ABS) emphasized that health and safety communication channels should be established vertically and horizontally within the organization. Vertical channels provide communication between managers and employees within the hierarchical structure of the organization, while horizontal channels provide communication between employees at the same level within the hierarchical structure. It was emphasized that managers should be prepared to listen as well as speak for the success of vertical communication, while the importance of all employees having the necessary knowledge for safe operations was underlined for the success of horizontal communication. (ABS, 2012).

\section{Just, Reporting and Learning Culture}

Just Culture is a culture in which employees are not punished for their mistakes, omissions or decisions which are commensurate with their experience and training, but where explicit negligence, conscious violations and destructive acts are not tolerated (Eurocontrol, n.d.). In addition, reporting an accident or a near-miss construct the database of a safety system -learning culture- where the predicted actions are taken. A just culture signifies the need to establish well communication and training initiatives and advance arrangements in the maritime domain. Employees should feel free to report any safety issues without fear of being blamed, and the organisation should have the willingness and capability to learn from this information to improve their safety performance and to minimize the risks of reoccurrence of these accidents. Reason (1998), Hudson (1999) and Westrum (1993) determined that the flow of information in a safety system is one of the main elements to improve safety. Also, Reason (1998) pointed out that safety culture is the equivalent of the informed culture which is established by just, report, learning and flexible culture. Therefore, necessary arrangements should be existed for reporting safety issues in an organization.

\section{Flexible Working Environment}

The maritime sector includes a high-level of occupational risk due to enables the handling and transportation of large tonnage goods in a short time. Achieving and maintaining a positive safety culture will create a flexible working environment for employees in an organization automatically. Besides, organizations should provide sufficient time to employees for safe operation. The possibility of making mistakes increases as a result of excessive fatigue of employees during working hours or working within an inflexible working environment (HSE, 2002). During the high tempo cargo operations or certain kinds of danger, the organizations that are able to configure themselves from a conventional hierarchical model to a flexible mode as "more horizontal than vertical", might minimize the risks of accidents by minimizing the pressure on the employees (Transportation Research Board, 2015). Creating a flexible working environment requires the organization's leaders to look at the whole picture and focus on how to get the safety work done, not just completion of work, and requires effectively communicate with employees.

\section{Occupational Hazards and Accidents in Container Ports}

More than 80 per cent of global trade consists of shipping transports all over the world. Shipping is a cost-effective way of international transportation for large tonnage goods. Container shipping plays an increasingly significant role in international trade especially in terms of enables to handling various types of goods at once. In 2018, the global containerized trade increased by 2.6 per cent and reached 152 million TEUs (UNCTAD, 2020). Nowadays, occupational accidents that occur in container ports not only cause physical or mental harm to employees but also damage port operators by causing trained and experienced employees to quit their jobs.

International Labour Organization (ILO) defines occupational accident as an occurrence arising out of or during work (ILO, 1996). Ports play a fundamental role in linking sea and land transportation. Especially, they become rather complex systems due to the variety of goods (Antão et. al., 2016). Therefore, ports are potentially high-risk environments to work in (HSE, 2011).

Container terminals are hazardous workplaces due to involving several risky operational activities such as operating cranes, lashing, electrical repairs, tally operations and truck driving (Lu and Kuo, 2016). As technology advances, the charging/discharging operation process in container ports becomes shorter. Besides that, a container port needs sufficient-size aprons, qualified employees and equipment in order to handle various types of containers. Accidents and incidents mostly occur in container ports and terminals in the case of safety violations or omissions. Occupational Safety and Health Administration in the United States declared that over 100 employees' deaths and nearly 95,000 injuries occur each year because of improper use of equipment in container terminal operations (Lu and Yang, 2010).

In the study, potential occupational accidents which might occur in a container port/terminal during any operation such as mooring/unmooring, cargo handling, stowing, transportation, routine/non-routine maintenance etc. were identified through the meticulous literature-based review. The most common 10 accidents that are exposed to container terminals were examined in the study. In addition, 28 sub-categories of the main accidents were also determined to elaborate on the research. Subcategories listed under the type of accident area to which it relates is given in Table 1. 
Table 1. Common Accidents in Container Ports and Terminals

\begin{tabular}{|c|c|c|}
\hline Quality of Accident & Sub-accidents & \\
\hline \multirow{2}{*}{$\begin{array}{l}\text { Accidents Related to Lifting Equipment and Loads } \\
\text { Equipment and Loads }\end{array}$} & 1 & Person/equipment/object struck by a container \\
\hline & 2 & Person/equipment/object struck by lifting equipment \\
\hline \multirow{5}{*}{ Body Part Injuries and Disorders } & 3 & Musculoskeletal disorders MSDs due to manual handling or excessive force \\
\hline & 4 & Body parts cut or contusion due to manual handling \\
\hline & & \\
\hline & 5 & Back pain or muscle injuries due to manual handling or excessive force \\
\hline & 6 & Person struck by a fixed object or fixed terminal structure \\
\hline \multirow{2}{*}{ Collapse of a Container Stack } & 7 & Person crushed under the collapse of a container stack \\
\hline & 8 & Property damaged by collapse of a container stack \\
\hline \multirow{3}{*}{ Electric Shocks } & 9 & Electric shocks due to contacting with an electrical energy source \\
\hline & 10 & Fire due to excessive heating caused by an electric leakage \\
\hline & 11 & Fire due to ignition of a combustible object by a spark generated by an electric source \\
\hline \multirow{4}{*}{ Exposure to Chemical or Harmful Substance } & 12 & Body parts burns due to exposure to chemical substance \\
\hline & 13 & Chemical splash in the eye \\
\hline & 14 & Respiratory Problems due to hazardous gases in a long period \\
\hline & 15 & Inhalation exposure to toxic gases \\
\hline \multirow{3}{*}{ Fall from Height } & 16 & Person falls from height whilst working near an unprotected open edge \\
\hline & & \\
\hline & 17 & Person falls from height due to unsafe access \\
\hline \multirow{3}{*}{ Falling Objects } & 18 & Person injuries due to an unsecured falling object \\
\hline & 19 & Property damaged by an unsecured falling object \\
\hline & 20 & Person crushed against a falling object \\
\hline \multirow[b]{2}{*}{ Fire / Explosion } & 21 & Fire due to incorrect separation or segregation of dangerous goods in containers \\
\hline & 22 & Fire due to unsafe practices near to combustible or explosive substance \\
\hline \multirow{2}{*}{ Slips, Trips and Falls } & 23 & Person slips, trips and falls whilst working on slippery surfaces \\
\hline & 24 & Person slips, trips and falls due to presence of a loose/unsecured equipment or object \\
\hline \multirow{4}{*}{ Workplace Transport Accidents } & 25 & Person struck by a vehicle \\
\hline & 26 & Person crushed against a vehicle \\
\hline & 27 & Collision between a fixed object and a vehicle \\
\hline & 28 & Collision between vehicles \\
\hline
\end{tabular}

\section{Visited Container Ports/Terminals}

As the main component of maritime transportation, container shipping plays an increasingly significant role in international trade. The total number of TEU handled in Turkey's container ports is 10,843,998 (Ministry of Transportation and Infrastructure, 2018). Four sea regions in Turkey have quite strategic points in terms of shipping 
trade; Marmara Region, Aegean Region, Mediterranean Region, Black Sea Region and $61.65 \%$ of the total container trade (Ministry of Transportation and Infrastructure, 2018) is carried in Marmara Region. Within the scope of the study, six container ports/terminals located in the Marmara Region were selected to conduct a questionnaire with port workers and to carry out an interview with occupational safety specialists. These ports are given below in Figure 3.

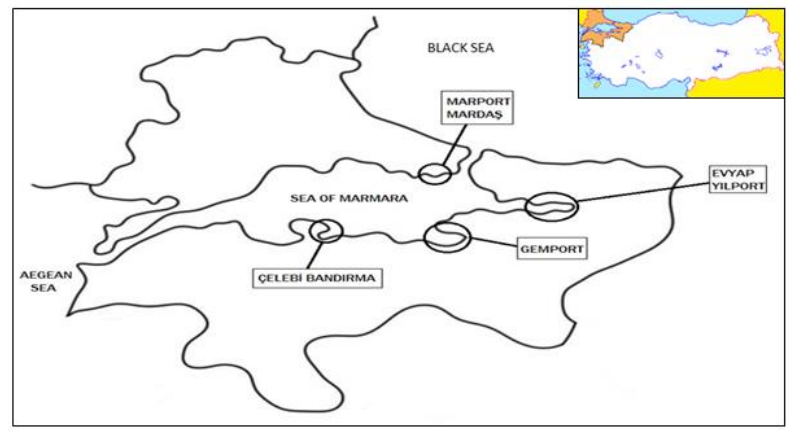

Figure 3. Visited Ports/Terminals in the Marmara Region

\section{Materials and Methods}

The effects of Safety Culture on occupational accidents in container terminals/ports was investigated in the study and measurement questionnaire which was generated based on the literature was applied to 134 port workers in the sample. The accepted 100 questionnaires were analysed using SPSS 22 software in order to examine mainly correlation between safety culture and accident occurrences in the container terminals. Independent samples t-test, chi-square test and descriptive statistics that are used to describe basic features of the data were used to test the hypotheses.

\section{Questionnaire and Survey Respondents}

The survey method was designed to gather respondents' information (age, gender, job title and work field), to analyse safety culture variables and to investigate occupational accidents, respectively.

Safety culture consisting of 6 components and 20 variables in the questionnaire were determined; Commitment and Safety Awareness (4 variables), Training and Supervision (4 variables), Behaviours (4 variables), Communication (2 variables), Just, Reporting and Learning Culture (4 variables), Flexible Working Environment (2 variables). Variables were also determined to detect the correlation between safety culture and accident occurrences and to evaluate differences in the safety culture level of the port workers The participants were asked to evaluate the variables with 'agree' and 'disagree'. Cronbach's Alpha reliability coefficient was calculated as 0.921 .

For the purpose of gathering data, a survey has been conducted with 134 respondents and current accepted 100 questionnaires were analysed, and the interview has been carried out with the occupational safety specialists of six container ports/terminals that mentioned above. Accordingly, the following hypotheses were proposed;

H1: There is a significant correlation between safety culture and occupational accidents.

$\mathrm{H} 2$ : There are significant differences between the safety culture scores of each occupational group.

- To examine the relationship between safety culture and accident occurrences, "Independent samples t-test" was used.

- To examine the differences in the safety culture scores of the port workers, the whole data were analysed to reach a general statement on a safety culture level. Each variable had the same score which is 1 . After finding the total score of all respondents (maximum score is 20), the new data was analysed by "chi-square test" to find these separation points.

- To examine the differences between the safety culture scores of occupational groups, "Independent samples t-test" was used.

Potential hazards and accidents occurred in the ports/terminals were classified under the 10 main accident categories so gathering unnecessary data was prevented. In case of that, the respondents had or witnessed an accident, the type of accidents, the work environment related to accidents, the severity of injuries and occupational groups were also examined by descriptive statistical methods.

\section{Results and Discussion \\ Correlation between Safety Culture Components and Accident Occurrences}

In order to investigate the impact of the safety culture on the occupational accident occurrences, the correlation between safety culture components and occupational accidents was examined by developing the $\mathrm{H} 1$ hypothesis.

H1: There is a significant correlation between safety culture scores and occupational accidents. A simple correlation test (Pearson correlation coefficient) was applied to test the hypothesis. The results obtained from the analysis of the hypothesis $\mathrm{H} 1$ are given in Table 2.

The $\mathrm{H} 1$ hypothesis was accepted and the results have clearly demonstrated that as the safety culture level (was determined with safety scores of port workers) increased in an organization, the port workers become more aware of safety and they behave in a positive way to avoid accidents.

The differences in Flexible Working Environment and Just, Report and Learning Culture components were determined bigger than compare to others. Significant differences point out that the respondents, who evaluate the variables of these components negatively, tend to expose to an accident more. 
Table 2. A Simple Correlation Analysis for Components of the Safety Culture and the Accident Occurrences

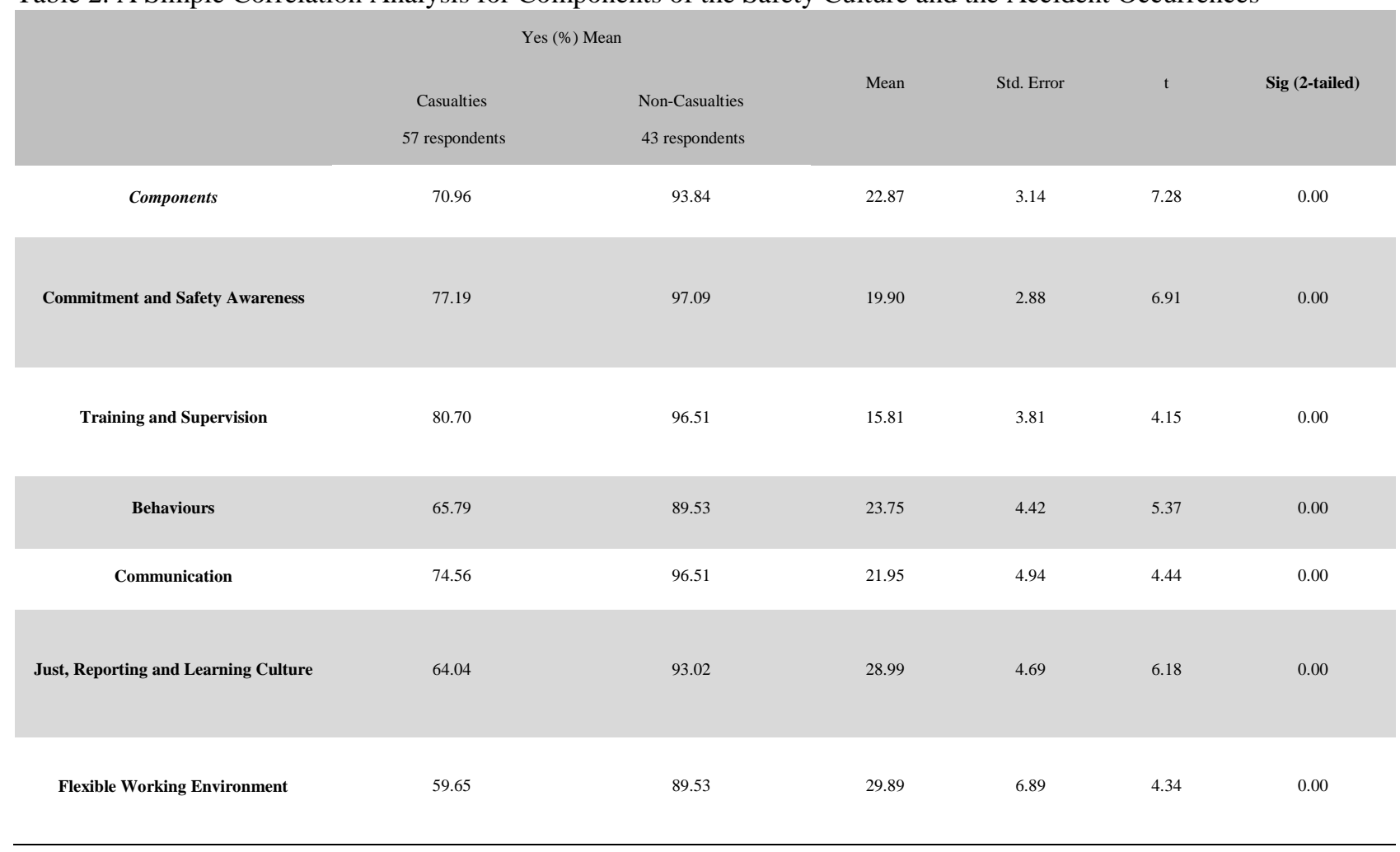

\section{Safety Culture Level of the Port Workers}

Differences in the safety culture level of the port workers based on accident occurrences were analysed by chisquare test and the scores are given below in Table 3.

Table 3. Points of Separation of Safety Culture Score of the Respondents

\begin{tabular}{llllll}
\multicolumn{7}{c}{ Safety Culture Scale } & X2 & $\mathrm{p}$ \\
& $\leq 10$ & $11-16$ & $17 \leq$ & & \\
\hline Having an Accident (\%) & 100 & 88.5 & 33.3 & 34.77 & 0.00 \\
\hline
\end{tabular}

All port worker who got 10 points or below had an accident. $88.5 \%$ of the port workers who got between 11 and 16 points had an accident and $33.3 \%$ of the port workers who got above 17 points had an accident. The separation scores were found as statistically significant $(\mathrm{p}=0.00)$. Besides, in terms of the work environment $14 \%$, $26 \%$ and $60 \%$ of the port workers were found in a highrisk area, medium risk area and low-risk area expose to an accident, respectively.

Table 4. Accident Risk based on Safety Culture Level of the Port Workers

\begin{tabular}{ccccc}
$\begin{array}{c}\text { Casualtie } \\
\text { s }\end{array}$ & $\begin{array}{c}\text { Non- } \\
\text { Casualties }\end{array}$ & $\begin{array}{c}\text { Total } \\
(\%)\end{array}$ & $\begin{array}{c}\text { Score } \\
\text { s }\end{array}$ & $\begin{array}{c}\text { Accident Risk } \\
\text { Areas }\end{array}$ \\
\hline 14 & 0 & $14 \%$ & $<10$ & High Risk Area \\
23 & 3 & $26 \%$ & $11-17$ & Medium Risk Area \\
\hline 20 & 40 & $60 \%$ & $17>$ & Low Risk Area \\
\hline
\end{tabular}

\section{Occupational Accidents in Container Ports}

In the study, container port accidents were examined and especially 10 types of accidents were found more common. These types of accidents were codified in the study as given below in Table 5 .

\section{Table 5. Codes of Accidents}

\begin{tabular}{|ll}
\hline A1 & \multicolumn{1}{c}{ Accidents } \\
\hline A2 & Body Injuries and Disorders \\
\hline A3 & Collapse of a Container Stack \\
\hline A4 & Electric Shocks \\
\hline A5 & Exposure to Chemical or Harmful Substance \\
\hline A6 & Fall from Height \\
\hline A7 & Falling Objects \\
\hline A8 & Fire / Explosion \\
\hline A9 & Slips, Trips and Falls \\
\hline A10 & Workplace Transport Accidents \\
\hline
\end{tabular}

When data analysed, A10 (23\%), A9 (22\%) and A2 (20\%) types of accidents were found to be seen most respectively. However, A3 (1\%) type accidents was found to be less than others; A1 (13\%), A5 (5\%), A6 (6\%), A4 (4\%), A7 (3\%) and A8 (3\%). 


\section{Accident Areas}

Ports play a fundamental role in the transportation and they have become complex systems due to intense cargo traffic (Antão et. al., 2016). Therefore, work environment safety related to accidents was examined in the study. The areas where the accidents commonly occurred in the ports are given below in Figure 4.

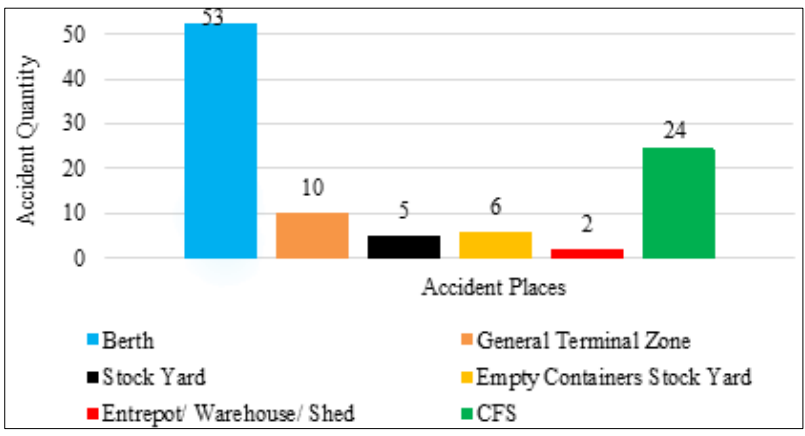

Figure 4. Distribution of Accidents by Workplace

Accidents have intensely happened around the berth area that is the interface between ship and shore and including high-risk handling equipment. Container Freight Station (CFS) was detected as a secondary area that accidents commonly happened. These two areas are the functional part of a container port in terms of cargo operation; involving heavy traffic of vehicles, port workers, containers and operational equipment.

\section{The Severity of Injuries and Occupational Groups}

The analysis of the injuries has shown that $62 \%$ of total accidents ended up with an injury and $2 \%$ of them ended up with death. The rest of the respondents $(36 \%)$ have survived the accidents without any injury. Although the getting injured ratio is high, $92 \%$ of the injuries were found to be slight, and $8 \%$ were found to be serious. Container terminals are the high-risk areas due to nature of work. However, when the accidents were examined, it was seen that each occupational group was exposed to different frequently accidents. In order to examine the differences between the safety culture scores of occupational groups $\mathrm{H} 2$ hypothesis was developed.

$\mathrm{H} 2$ : There are significant differences between the safety culture scores of each occupational group.

Independent samples t-test was applied to test the hypothesis. The results obtained from the analysis of the hypothesis $\mathrm{H} 2$ are given below.

The analysis revealed that the occupational groups exposing to accidents mostly were Tallymen (16\%), Crane Operators (14\%) and CFS Personnel (13\%), respectively. Dockworker (9\%), Field Operation Personnel (9\%), Ship Operation Personnel (7\%), Stockyard operator (5\%), Superintendent for Field Operation (4\%), Superintendent for Ship Operation (5\%) and Technical Maintenance Personnel (4\%) are the following occupational groups exposed to accidents. According to comparative analysis, negatively low-level correlation (Pearson correlation $\mathrm{r}=-0,137$ and sig= 0,001 ) was found between the occupational groups' safety culture score and the exposure to the accidents. The $\mathrm{H} 2$ hypothesis was accepted.

\section{Conclusion and Suggestion}

There are several factors affecting safety both at the organizational and individual level and safety culture is one of the most important of them. The study has revealed that positive safety culture in an organization has a strong influence on employees in terms of avoiding accidents, as well as safety rules and regulatory procedures.

Port workers are key actors for the safety work environment in the maritime industry. One important general implication from the study is that, as the safety culture of port workers increases, the accidental exposure rate decreases.

The study also illustrates that getting different-level safety training in an organization may be one of the reasons why each occupational group was exposed to a different rate of accidents. Comparisons between occupational groups concerning their evaluation of safety culture components revealed that Tallymen's safety scores were generally lower than the others. Then again, their accidental rate was found more than all workgroups. Therefore, it is suggested that the safety management system of an organization should be properly checked, qualified employees should be selected for the appropriate job, and if neither of these, all employees should be systematically involved in safety training.

Among all components of safety culture, flexibility was found to be especially an important factor in accidents. It was clearly seen that port workers who negatively answer the variables of Flexible Working Environment tend to expose to more accidents. The working hours, fatigue, and work pressure were the determinants for port workers' evaluations.

To sum up, the safety culture should be considered as a proactive safety indicator and organizations should take timely precaution by monitoring their safety management systems and by assessing their safety culture level.

It should not be forgotten that safety starts with the individual. Therefore, steps should be taken to vaccinate the concept of safety culture starting with the individual to the organizational level. Safety training should involve all employees in an organization to improve their perception level of safety and to create awareness. Additionally, organizations should be transparent about their safety policy and deficiencies safety-related issues.

Container ports/terminals are one of the high-risk areas in the maritime industry. Allocated time for the tasks should be enough to do these tasks in safe manners. Stress factors and lack of attention are the main cause of accidents and incidents. So, working hours should be arranged with respect to the level of effort and fatigue of port workers properly. 


\section{Acknowledgements}

The authors acknowledge with grateful thanks to the cooperation of ÇELEBI PORT OF BANDIRMA, EVYAPPORT, GEMPORT, MARDAŞ PORT, MARPORT and YILPORT for making possible and coordinating the visits, cooperation and invaluable comments.

\section{References}

Afifi, A. (2015). Safety Culture History and Theory.

American Bureau of Shipping (ABS) (2012). Guidance Notes on: Safety Culture and Leading Indicators of Safety.

Antão, P., Calderón, M., Puig, M., Michail, A., Wooldridge, C., Darbra, R. M. (2016). Identification of Occupational Health, Safety, Security (OHSS) and Environmental Performance Indicators in Port Areas. Safety Science, 85, 266-275. dx.doi.org/10.1016/j.ssci.2015.12.031.

Berg, HP. (2013). Human Factors and Safety Culture in Maritime Safety, TransNav the International Journal on Marine Navigation and Safety of Sea Transportation, 7(3): 343-352, doi.10.12716/1001.07.03.04.

Bhattacharya, Y. (2015). Measuring Safety Culture on Ships Using Safety Climate: A Study among Indian Officers. International Journal of e-Navigation and Maritime Economy, 3, 51-70. doi.org/10.1016/j.enavi.2015.12.006.

Cooper, M. D. (2000). Towards a model of safety culture. Safety Science. $36 \quad$ (2), 111-136. https://doi.org/10.1016/s0925-7535(00)00035-7.

Cooper, M. D. (2001). Improving Safety Culture: A Practical Guide.

Cox, S., , Flin, R. (1998). Safety culture: Philosopher's stone or man of straw? Work and Stress, 12(3), 189201. doi.org/10.1080/02678379808256861

Drupsteen, L., , Boustras, G. (2015). Exploring effectiveness of safety information for workplace visitors. Safety Science, 88, 224-231. doi.org/10.1016/j.ssci.2015.11.017.

Ek, Å., Akselsson, R. (2005). Safety culture on board six Swedish passenger ships. Maritime Policy and Management, 32(2), 159-176. doi.org/10.1080/03088830500097455.

Ek, Å., Runefors, M., Borell, J. (2014). Relationships between safety culture aspects - A work process to enable interpretation. Marine Policy, 44, 179-186. doi.org/10.1016/j.marpol.2013.08.024.

Eurocontrol (n.d.). Supporting European Aviation.

Glendon, A. I. and Stanton, N. A. (2000). Perspectives on safety culture. Safety Science. 34, 193-214. doi.org/10.1016/S0925-7535(00)00013-8.

Hahn, S. E. and Murphy, L. R. (2008). A short scale for measuring safety climate. Safety Science. 46(7), 10471066. doi.org/10.1016/j.ssci.2007.06.002.

Havold, J. I. (2000). Culture in maritime safety. Maritime Policy Management. 27, 79-88. doi.org/10.1080/030888300286716 .

Havold. J. I. (2007). National cultures and safety orientation: A study of seafarers working for
Norwegian shipping companies, Work, Stress, 21:2, 173-195. doi.org/10.1080/02678370701424594.

Health and Safety Executive (2000). Safety Culture Maturity Model. Offshore Technology Report 2000/049.

Health and Safety Executive (2001). Safety Climate Measurement User Guide and Toolkit.

Health and Safety Executive (2002). Safety Culture: A review of the literature.

Health and Safety Executive (2005). A Review of Safety Culture and Safety Climate Literature for the Development of the Safety Culture Inspection Toolkit, Research Report 367.

Health and Safety Executive (2011). A Quick Guide to Health and Safety in Ports.

Hudson, P. (1999). Safety Culture Theory and Practice. Center for Safety Science. RTO MP-032, Presented at RTO HFM Workshop, The Human Factor in System Reliability-Is Human Performance Predictable?

ICAO (2006). Safety Management, Global Approach Unlocks Potential of SMS. The magazine of the International Civil Aviation Organization, Vol 61(6).

IMO (2003). Role of the Human Element, MSC 77/17.

International Labour Organization (ILO) (1996). Recording and notification of occupational accidents and diseases.

Lu C. and Kuo S. (2016). The Effect of Job Stress on SelfReported Safety Behaviour in Container Terminal Operations: The Moderating Role of Emotional Intelligence. Transportation Research Part F: Traffic Psychology and Behaviour, 37, 10-26. dx.doi.org/10.1016/j.trf.2015.12.008

Lu C. and Yang C. (2010). Safety Leadership and Safety Behaviour in Container Terminal Operations. Safety Science, $\quad 48(2), \quad 123-134$. doi.org/10.1016/j.ssci.2009.05.003

Lu, C. S. and Tsai, C. L. (2010). The effect of safety climate on seafarers' safety behaviours in container shipping. Accident Analysis , Prevention . 42(6), 19992006. doi.org/10.1016/j.aap.2010.06.008

Marais, K., Dulac, N. and Leveson N. (2004). Beyond Normal Accidents and High Reliability Organizations: The Need for an Alternative Approach to Safety in Complex Systems. Engineering Systems Division Symposium, Massachusetts Institute of Technology, Cambridge, MA.

Martyka J. and Lebecki K. (2014). Safety Culture in HighRisk Industries. International Journal of Occupational Safety and Ergonomics, 20:4, 561-572.

Ministry of Transportation and Infrastructure (2018). Marine Trade 2018 Statistics (In Turkish).

Motter, A.A. and Santos, M. (2017). The Importance of Communication for the Maintenance of Health and Safety in Work Operations in Ports. Safety Science, 96, 117-120. doi.org/10.1016/j.ssci.2017.03.020

O'Toole, M. (2002). The relationship between employees' perceptions of safety and organizational culture. Journal of Safety Research, 33(2), 231-243. doi.org/10.1016/S0022-4375(02)00014-2.

Reason, J. (1998). Achieving a safe culture: Theory and practice. Work, Stress, 12(2), 293-306. doi.org/10.1080/02678379808256868. 
Simone, De, S. (2014). The Affective Component of Workplace in Organizational Behaviour Studies, American International Journal of Contemporary Research, 4(9), 38-43.

Terzi, H., Gazioğlu, C. (2014). Finding Solutions before Accidents Happen, XVIII. IALA AISM 2014.

Terzi, H., Gazioğlu, C. (2014). Pozitif Emniyet Kültürü Temel Öğelerini Esas Alan Kazasay Olayları (Near Miss) Raporlama Sistemi. Dokuz Eylül Üniversitesi Denizcilik Fakültesi Dergisi, 6(1), 23-58.

Terzi, H., Gazioğlu, C. (2016). New Era In Maritime Safety: Safety Culture, 13th International IALA VTS Symposium, International framework for VTS and national regulatory provisions.

Transportation Research Board (2015). Improving Safety Culture in Public Transportation. Transit Cooperative Research Program, Report 174.

United Nations Conference on Trade and Development [UNCTAD]. (2020). Review of Maritime Transport.

Vega, JL. (2002). Safety Culture in Shipping, WMU Journal of Maritime Affairs, 1, 17-31.

Westrum R. (1993). Cultures with Requisite Imagination. In: Wise J.A., Hopkin V.D., Stager P. (eds) Verification and Validation of Complex Systems: Human Factors Issues. NATO ASI Series (Series F: Computer and Systems Sciences), vol. 110. Springer, Berlin, Heidelberg. doi.org/10.1007/978-3-66202933-6_25.

White, C. (2017). What does Safety Commitment Mean to the Employee?

Yüce H., Gazioğlu C. (2006). Maritime Security Challenges Ahead in the Black Sea, Journal of Black Sea/Mediterranean Environment, Vol.12 (3): 233250.

Yücel, M, Yurtören, C. (2019). Determination of Risk Factors Caused By Ships in Port Planning. International Journal of Environment and Geoinformatics, 6(3), 254-263. doi: 10.30897/ijegeo.641434.

Zohar, D. (1980). Safety climate in industrial organizations: theoretical and applied implications. Journal of Applied Psychology. 65(1), 96-102. doi.org/10.1037/0021-9010.65.1.96 